\title{
Seafloor morphology and acoustic facies of the George V Land shelf
}

\author{
Robin J. Beaman ${ }^{\mathrm{a}, *}$, Peter T. Harris ${ }^{\mathrm{b}}$ \\ ${ }^{a}$ School of Geography and Environmental Studies, University of Tasmania, GPO Box 252-76, Hobart 7001, Tasmania, Australia \\ ${ }^{\mathrm{b}}$ Antarctic CRC and Australian Geological Survey Organisation, University of Tasmania, GPO Box 252-80, Hobart 7001, \\ Tasmania, Australia
}

\begin{abstract}
To study the seafloor morphology on the George V Land shelf, East Antarctica, over $2000 \mathrm{~km}$ of high-frequency 3.5-27 kHz, echo-sounder data were collected between February and March 2000. The shelf can be divided into four acoustic facies: (a) Type IA-2 seabed is ice-keel turbate found on mid- to outer-shelf banks on seafloor less than $500 \mathrm{~m}$ deep; (b) Type IB seabed is siliceous mud and diatom ooze drift, drape and fill deposits within the George V Basin between 750 and $850 \mathrm{~m}$ depth; (c) Type IIB seabed is smooth diamicton below $500 \mathrm{~m}$ depth, and occasionally has lowrelief megaflutes or ridge and swale features; (d) Type IIIC seabed is high relief ridges and canyons from the coast to the deepest part of the George V Basin. The acoustic facies are explained in terms of glacial and oceanographic influences on the shelf since the Last Glacial Maximum.
\end{abstract}

(C) 2003 Elsevier Science Ltd. All rights reserved.

\section{Introduction}

In February-March 2000, the joint Italian/ Australian Research Cruise to study the glacial history of Wilkes Land (Project WEGA) mapped a large part of the continental shelf off George V Land, East Antarctica (Brancolini and Harris, 2000). Using the research vessel Tangaroa, the aim of the WEGA project was to collect detailed sedimentary records from the George $\mathrm{V}$ Land continental margin, for which few data presently exist. The expedition mapped and ground-truthed the shelf predominantly between longitude $142^{\circ}$

\footnotetext{
*Corresponding author. Tel.: +61-3-6226-2497; fax: +61-36224-0282.

E-mail address: rbeaman@postoffice.utas.edu.au (R.J. Beaman).
}

and $146^{\circ}$ East, in the vicinity of the Mertz Glacier Tongue and over the George $\mathrm{V}$ Basin, a linear, inner-shelf basin that parallels the coast (Fig. 1; Domack, 1982). A large sediment drift deposit was discovered in the western part of the basin, and subsequently named the Mertz Drift (Harris et al., 2001). Sediment drifts are widely recognized in deep-sea environments (Faugères et al., 1999); however, only relatively recently sediment drifts have been found on the Antarctic continental shelf (Harris et al., 1999).

For this paper, we used echo-sounder data to investigate seafloor morphology and acoustic facies to interpret the most recent sedimentation processes that have been active on the George $\mathrm{V}$ Land shelf since the Last Glacial Maximum (LGM). With seabed penetration depths of approximately $50 \mathrm{~m}$, the use of echo-sounder data is 


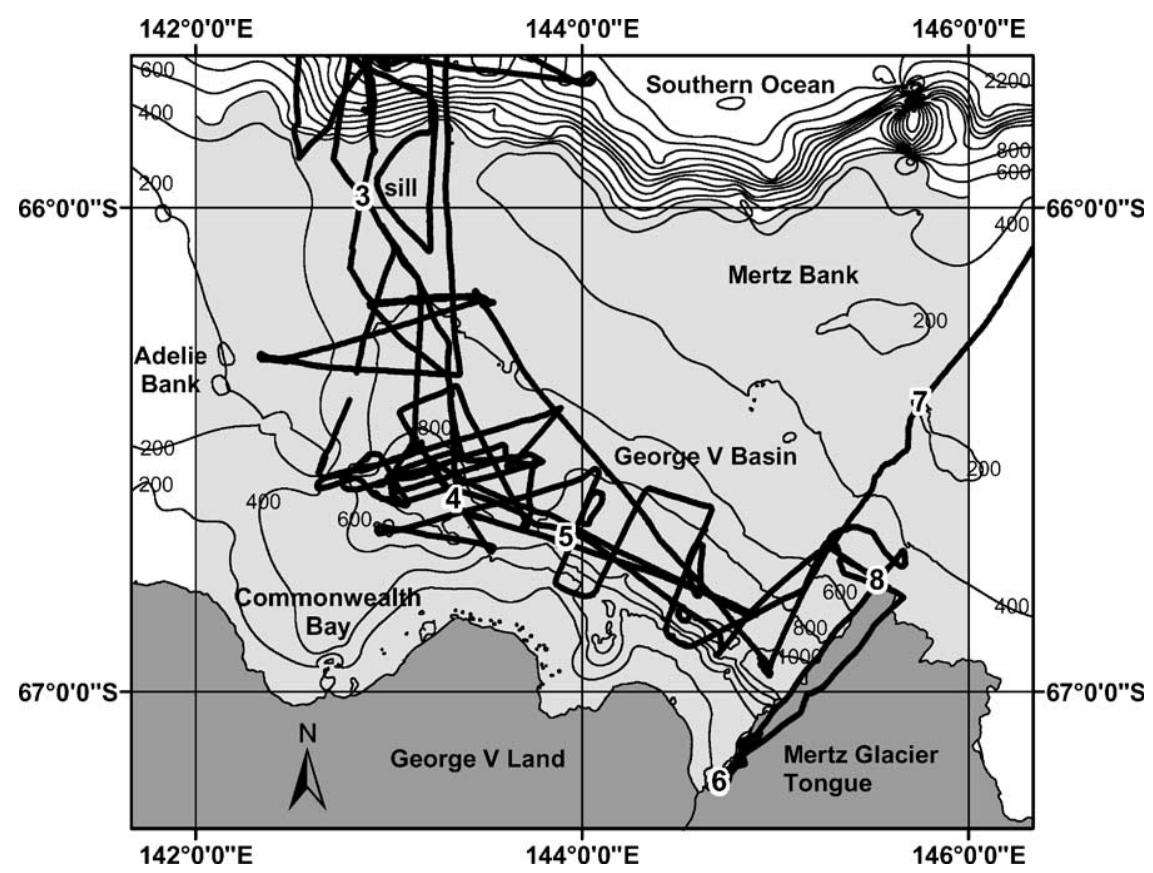

Fig. 1. Track map of the R.V. Tangaroa and features of the George V Land shelf. The data for the present report was compiled using over $2000 \mathrm{~km}$ of echo-sounder subbottom profiles from the WEGA expedition. The study also incorporates published information on seafloor morphology from previous studies to add to the areas that the Tangaroa did not traverse. The $200 \mathrm{~m}$ depth contours were drawn from a grid of merged GEBCO (IOC, 1997) depths and data collected by the Tangaroa. The coastline data (SCAR Antarctic Digital Database) shows an inaccurate position of the west calving face of the Mertz Glacier Tongue. The light grey shaded area on the shelf shows the limits of the study area: western boundary is longitude $142^{\circ}$ East; eastern boundary is longitude $146^{\circ}$ East; and between the coast and $500 \mathrm{~m}$ depth contour at the shelf break. Scale is approximately $180 \mathrm{~km}$ at latitude $66^{\circ}$ South. Bold numbers refer to the position of figures quoted in the text.

a useful, if limited, technique for studying the surficial marine geology of the uppermost part of the succession preserved on the George V Land shelf. The report should be considered a first assessment or baseline study into a hostile area of the ocean that is infrequently visited and not mapped to any comprehensive degree. This report provides the first stage of a study into benthic habitats on the George V Land shelf.

Damuth (1980) highlighted the usefulness of high-frequency $(3.5-12 \mathrm{kHz})$ echo-sounder data for studying near-bottom sedimentary processes in the deep sea. With an average shelf depth of about $500 \mathrm{~m}$ around Antarctica (Dunbar et al., 1985), high-frequency profiles also have proven quite useful on the East Antarctic shelf (Barnes, 1987; Domack et al., 1989; Karl, 1989; O'Brien and Leitchenkov, 1997). Within the study area, the first collections of sediments were during Douglas Mawson's 1911-14 Australasian Antarctic Expedition to Commonwealth Bay (Chapman, 1922) then again by Mawson in the 1929-31 BANZARE expedition (Von der Borch and Oliver, 1968). Vanney and Johnson (1979) provided a seafloor morphology map of Terre Adélie based upon echo sounding data from a number of cruises to the area in the 1960s and 1970s. The next marine geological study to the area was not until 1978/ 1979 during 'Operation Deep Freeze' by the US Icebreaker Glacier, and provided the material for the first surficial sedimentary maps of the George V Land continental shelf (Domack, 1982; Domack, 1988; Domack and Anderson, 1983; Domack et al., 1989; Leventer, 1992). Later cruises to the area have made use of sidescan technology to investigate iceberg scour features on the 


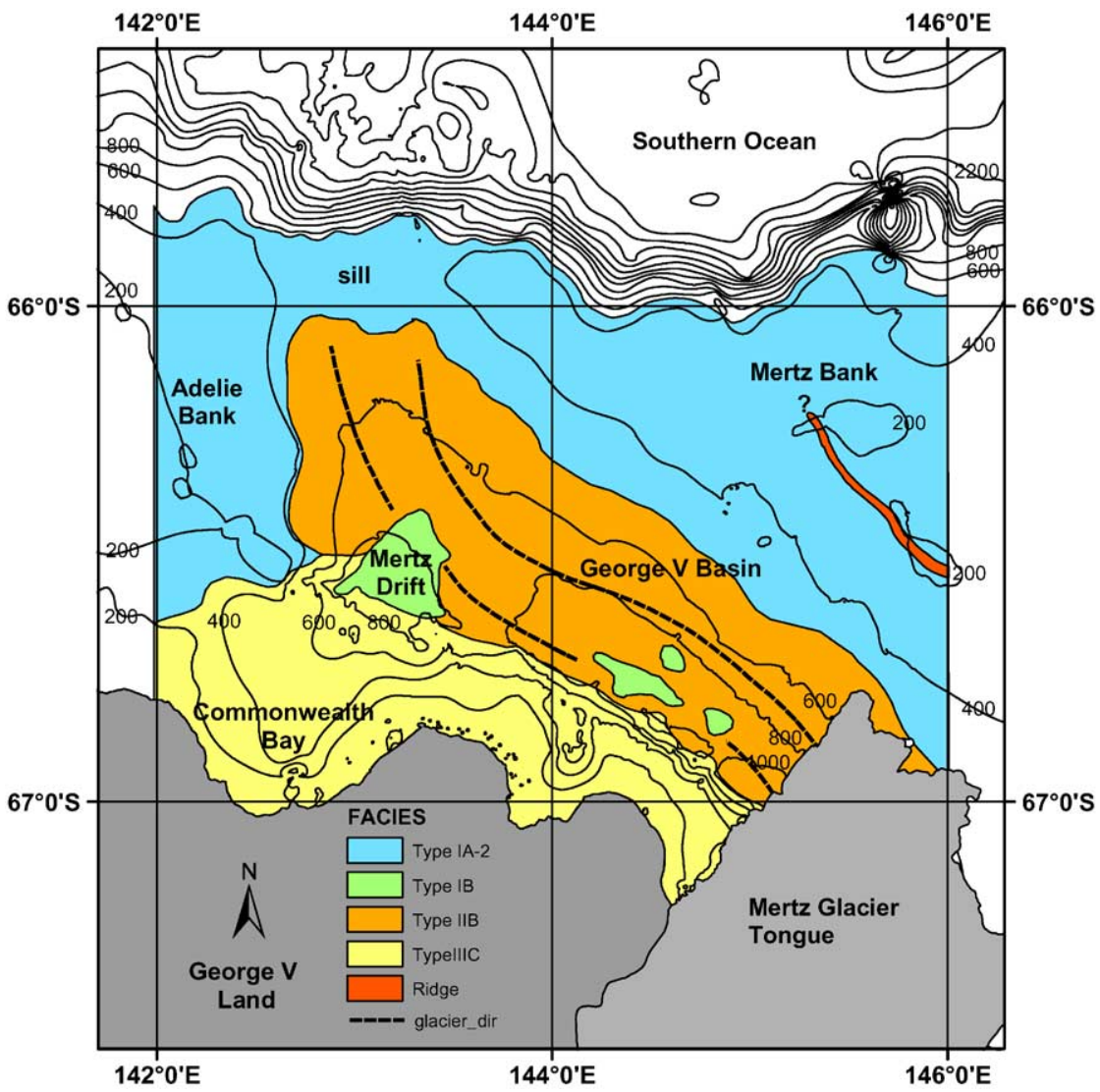

Fig. 2. Acoustic facies of the George V Land shelf: (a) Type IA-2 seabed - an ice-keel turbate found on the mid- to outer-shelf where the seabed is less than $500 \mathrm{~m}$ deep. (b) Type IB seabed-SMO drift, drape and fill deposits within the George V Basin predominantly below $750 \mathrm{~m}$ depth. (c) Type IIB seabed - smooth diamicton and subglacially formed megaflutes, or ridges and swales, within the George V Basin where the seabed is below $500 \mathrm{~m}$ depth. (d) Type IIIC seabed-high relief ridges and canyons on the inner-shelf, in depths from the coastline to below $1000 \mathrm{~m}$ depth in the George V Basin, comprised mostly of exoded crystalline basement outcrop. A ridge or lateral moraine in depths of approximately $200 \mathrm{~m}$ along the southern side of the Mertz Bank records the northern limit of the expanded Mertz Glacier during the LGM. The dashed 'glacier_dir' lines represents the direction of glacial advance along the axis of the George V Basin, interpreted from the position and orientation of megaflutes seen in echo-sounder profiles. Acoustic facies were interpreted from WEGA expedition data and other published reports.

relatively shallow, outer-shelf Mertz Bank (Barnes, 1987; Barnes and Lien, 1988). More recently, the area was visited by the research vessel Nathaniel $B$. Palmer (Leventer et al., 2001). The data for the present report were compiled using over $2000 \mathrm{~km}$ of echo-sounder subbottom profiles from the WEGA expedition. The acoustic facies map (Fig. 2) also incorporates published information on seafloor morphology from previous studies to add to the areas that the Tangaroa did not traverse.

\section{Physiographic setting}

The area of study on the shelf off George V Land is restricted to a western boundary of longitude $142^{\circ}$ East, an eastern boundary of longitude $146^{\circ}$ East, the coastline to the south, and the $500 \mathrm{~m}$ depth contour at the shelf break (Fig. 1). This represents a north to south shelf width of approximately $130 \mathrm{~km}$ and an east to west distance of about $180 \mathrm{~km}$, or an area of approximately $21,000 \mathrm{~km}^{2}$. The physiography of the shelf 
is dominated by the George $\mathrm{V}$ Basin, also called the Mertz Ninnis Trough or the Adélie Depression. The basin is over $1300 \mathrm{~m}$ deep just to the west of the Mertz Glacier Tongue. It parallels the George $\mathrm{V}$ Land coast and shoals to a depth of approximately $800 \mathrm{~m}$ before deepening again northeast of Commonwealth Bay. The basin then veers north and gradually shoals towards the shelf break, reaching a sill separating the basin from the continental slope at a depth of between 400 and $500 \mathrm{~m}$. The George V Basin is bounded to the north and west by the Mertz and Adélie Banks, respectively. These mid- to outershelf banks are relatively flat and are generally 200$400 \mathrm{~m}$ in depth (Domack, 1982).

\section{Data}

The data used in this study were primarily $3.5 \mathrm{kHz}$ echograms, obtained from an ORE Model No. 140 transceiver that printed to an EPC Model 9802 thermal printer. Secondary data sources were seafloor profiles from the ship-fitted $12.5 \mathrm{kHz}$ Simrad EK 500 echo sounder and a $27 \mathrm{kHz}$ Kaijo Denki echo sounder. Limited seismic profiles from a deep-tow Datasonics Chirp II acoustic profiler also provided a useful comparison against the results from the ship's echo sounders.

The Tangaroa logged GPS position, weather and depth data into a Data Acquisition System (DAS) every minute, and while over the continental shelf off George V Land, covered over $2000 \mathrm{~km}$ of sounding between 17 February and 3 March 2000. The positional data were put into the Geographic Information System ArcGIS as a point shapefile to show the ship's track (Fig. 1). Several small gaps in the track occur where the DAS failed for short periods of time. Echosounder depth was calculated from the sound velocity set to $1500 \mathrm{~m} / \mathrm{s}$. The ship initially approached the coast from the northeast, passing over the relatively shallow Mertz Bank, and performed conductivity, temperature, depth (CTD) casts over the deepest part of the George V Basin near the Mertz Glacier before sailing northwest along the axis of the basin. After discovery of the extent of the Mertz Drift, a siliceous mud and diatom ooze (SMO) drift deposit (Harris et al., 2001), a number of transects were run concentrating soundings over the western half of the basin before a final series of cores were obtained in this area. The ship transited several times north from this area, passing over the sill between the George V Basin and the continental slope.

For this project, all 1-min data points on the $3.5 \mathrm{kHz}$ echo-sounder rolls were inspected, compared with any secondary data sources, and an acoustic facies type recorded within the ArcGIS shapefile table. The overall pattern of results then formed the basis of polygons constructed in the GIS to infer the distribution of acoustic facies (Fig. 2). Classification of the seabed utilized the Damuth $(1978,1980)$ scheme, which is widely used for classifying deep-ocean sediments using $3.5 \mathrm{kHz}$ echograms. Maps were overlaid with $200 \mathrm{~m}$ depth contours drawn from a grid of merged GEBCO (IOC, 1997) depths and data collected by the Tangaroa.

\section{Acoustic facies results}

Four acoustic facies were distinguished in the study area (Fig. 2). Bottom echoes recorded distinct (Type IA-2 and IB), prolonged (Type IIB), and indistinct (Type IIIC) seabed types. In addition to these seabed classifications, the profiles were studied for any larger geomorphic features, such as the broad ridge found on the Mertz Bank.

\subsection{Distinct acoustic facies}

\subsubsection{Type $I A-2$}

This acoustic facies has sharp bottom echoes with no subbottom reflectors, and exhibits intense, close-spaced, regular hummocks (Fig. 3). Relief is generally no greater than 3-5 m. Type IA-2 seabed is found on the relatively shallow outer-shelf Mertz Bank in water depths of less than $500 \mathrm{~m}$, and on the sill connecting the George V Basin to the continental slope, also where the seabed is less than $500 \mathrm{~m}$ deep (Fig. 2). This echo type is identical to the ice-ploughed seafloor identified by Barnes and Lien (1988) and given the term icekeel turbate. The tilling action of grounded iceberg keels results in surficial sediments composed of a 


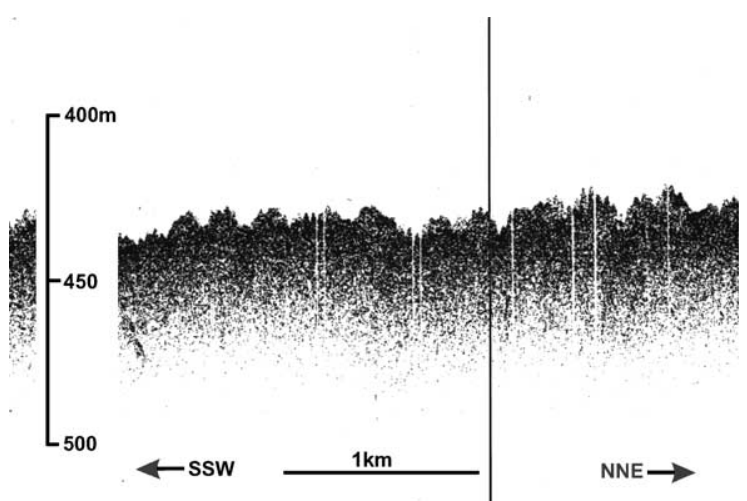

Fig. 3. Type IA-2 seabed $-3.5 \mathrm{kHz}$ profile showing intense, close-spaced, regular hummocks that generally have relief of no greater than $3-5 \mathrm{~m}$. This acoustic facies is found on mid- to outer-shelf banks in depths less than $500 \mathrm{~m}$. Other published reports contributed to interpretation of the seabed where the Tangaroa did not traverse. Sediments are an ice-keel turbate, or a heterogeneous mix of subseabed, ice-rafted and marine biogenic material (Barnes and Lien, 1988). The vertical scale in metres was calculated from sound velocity set to $1500 \mathrm{~m} / \mathrm{s}$. The image was collected on the sill between the George $\mathrm{V}$ basin and the continental slope in $435 \mathrm{~m}$ of water (Fig. 1).

heterogeneous mix of subseabed, ice-rafted and marine biogenic material (Barnes and Lien, 1988). The seabed morphology results of Barnes (1987) and the WEGA expedition were combined to produce a polygon representing a Type IA-2 seabed for depths of less than $500 \mathrm{~m}$, mostly on the mid- to outer-shelf and enclosing the George V Basin. The Adélie Bank, on the western side of the study site, is also assumed to include this seabed type as the physiography is similar to the Mertz Bank. Remotely sensed images of the region show grounded icebergs over the Adélie Bank and Mertz Bank (Massom et al., 2001), so even though the Tangaroa did not traverse across the Adélie Bank and all of the Mertz Bank, there is confidence that this seabed is most likely found on the mid- to outer-shelf in water depths of less than $500 \mathrm{~m}$. Therefore, the area covered by this acoustic facies is inferred to occupy the largest proportion of the shelf at approximately $49 \%$.

\subsubsection{Type $I B$}

Echograms show continuous, sharp bottom returns with up to ten, continuous and parallel subbottom reflectors, overlying a mostly smooth

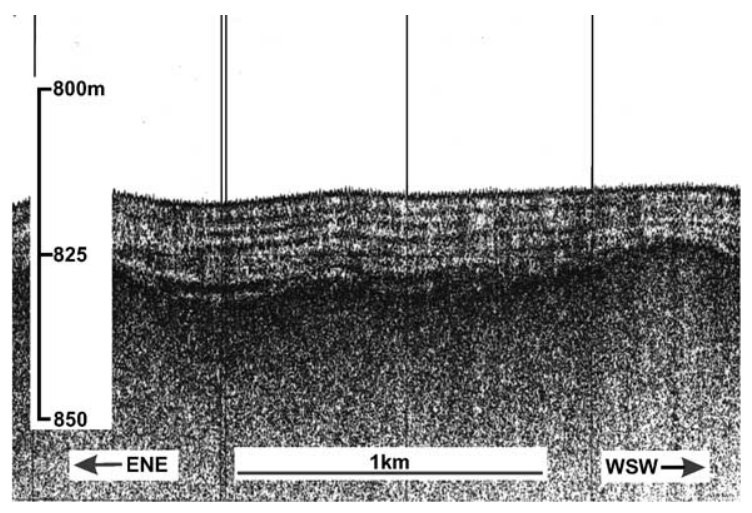

Fig. 4. Type IB seabed- $3.5 \mathrm{kHz}$ echogram showing continuous, sharp bottom returns with up to ten continuous and parallel subbottom reflectors, overlying a mostly smooth and prolonged echo. This acoustic facies coincides with SMO drift, drape and fill deposits overlying a smooth glacial diamicton, found below $750 \mathrm{~m}$ depth in the west half of the George V Basin (i.e. Mertz Drift), and below $850 \mathrm{~m}$ depth in the east half of the basin (three drape and fill deposits). The image shows a profile from the Mertz Drift in $815 \mathrm{~m}$ of water (Fig 1).

prolonged echo (Fig. 4). Type IB seabed coincide with an SMO drift deposit found below $750 \mathrm{~m}$ depth in the west half of the George V Basin (i.e. Mertz Drift; Harris et al., 2001) and below $850 \mathrm{~m}$ depth in the east half of the basin (three drape and fill deposits; Harris and Beaman, 2003). The SMO overlies a glacial diamicton (Domack and Anderson, 1983), and the contact between the two sediment types is very obvious. In the Mertz Drift, the parallel subbottom reflectors of this echo type generally pinch out at the edges and expand in thickness to a maximum of approximately $35 \mathrm{~m}$ near the centre of the drift deposit. The three drape and fill SMO deposits that occur in the east half of the basin generally show subbottom reflectors less than $3 \mathrm{~m}$ in thickness and expands to about $15 \mathrm{~m}$ thickness for the deposit located closest to the Mertz Glacier Tongue. The combined area of the SMO deposits is approximately $2 \%$ of the study area.

\subsection{Prolonged acoustic facies}

\subsubsection{Type IIB}

This echo type shows very prolonged bottom echoes with no subbottom reflectors (Fig. 5). It 


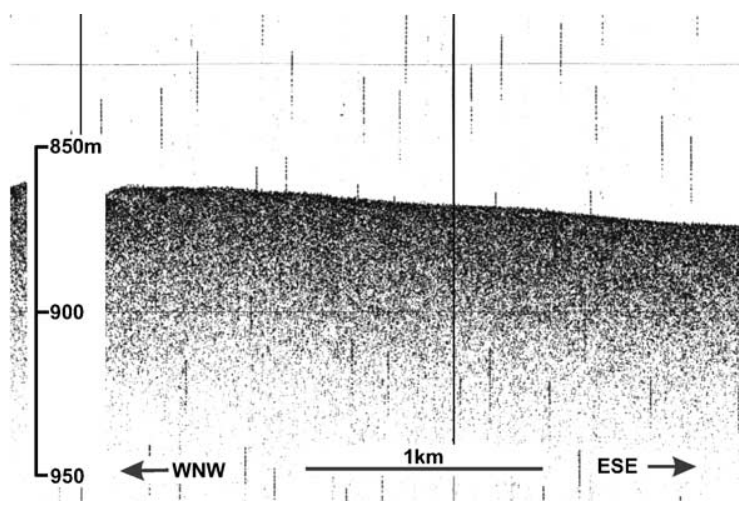

Fig. 5. Type IIB seabed $-3.5 \mathrm{kHz}$ profile showing very prolonged bottom echoes with no subbottom reflectors. It usually occurs with a smooth seabed but is occasionally interrupted by low relief, regular hyperbolae. The hyperbolae take the shape of mounds between 4 and $15 \mathrm{~m}$ above the seafloor, corresponding to megaflutes or ridge and swale features produced by subglacial moulding of the till at the glacier sole. Type IIB hyperbolae differ from Type IA-2 hyperbolae by generally being higher with more rounded crests and not as close-spaced. This acoustic facies occurs adjacent to the outer-shelf, ice-keel turbate Type IA-2, and deeper than $500 \mathrm{~m}$. Sediments are mostly grey, muddy diamictons (Domack, 1982). The image was collected over the inner George V Basin in $860 \mathrm{~m}$ of water (Fig. 1).

usually exhibits a smooth seabed but is occasionally interrupted by low relief, regular hyperbolae. The hyperbolae take the shape of mounds between 4 and $15 \mathrm{~m}$ above the seafloor, and differ from Type IA-2 hyperbolae by generally being higher with more rounded crests and not as close-spaced. The hyperbolae seen in the Type IIB seabed most probably correspond to megaflutes or ridge and swale features produced by subglacial moulding of the till at the glacier sole (O'Brien and Leitchenkov, 1997). Type IIB seabed corresponds to sediments of mostly grey, muddy diamictons (Domack, 1982), and often has a thin $(<30 \mathrm{~cm})$ surface layer of SMO (Brancolini and Harris, 2000). In other $3.5 \mathrm{kHz}$ studies on the Antarctic shelf such as in the Ross Sea, a prolonged bottom echo is also attributed to glacial diamicton (Karl, 1989). In the present study, Type IIB seabed occurs adjacent to the Type IA-2 ice-keel turbate, and deeper than $500 \mathrm{~m}$. The boundary between Types IA-2 and IIB seabed is gradational. The Mertz Drift appears to drape over the megaflutes in the western half of the George V Basin. The three discrete drape and fill SMO deposits in the eastern half of the basin also drape over the Type IIB seabed. The area of the shelf covered by the smooth Type IIB seabed is the second largest proportion at approximately $28 \%$.

\subsection{Indistinct acoustic facies}

\subsubsection{Type IIIC}

Regular, overlapping hyperbolae with varying vertex elevations above the seafloor and no subbottom reflectors characterize the Type IIIC seabed (Fig. 6). This echo type is found mostly along the inner-shelf side of the George V Basin, showing impressive vertical relief between the ridges and submarine canyons (Fig. 2). The inner-shelf appears incised by small gullies and canyons right to the deepest part of the basin. As an example, close to the outlet of the Mertz Glacier Tongue, in $550 \mathrm{~m}$ of water, pinnacles are $150 \mathrm{~m}$ high. Elsewhere on the inner-shelf side of the basin, relief of $100-150 \mathrm{~m}$ is present, even in depths of $1000 \mathrm{~m}$. Multi-channel seismic lines shot

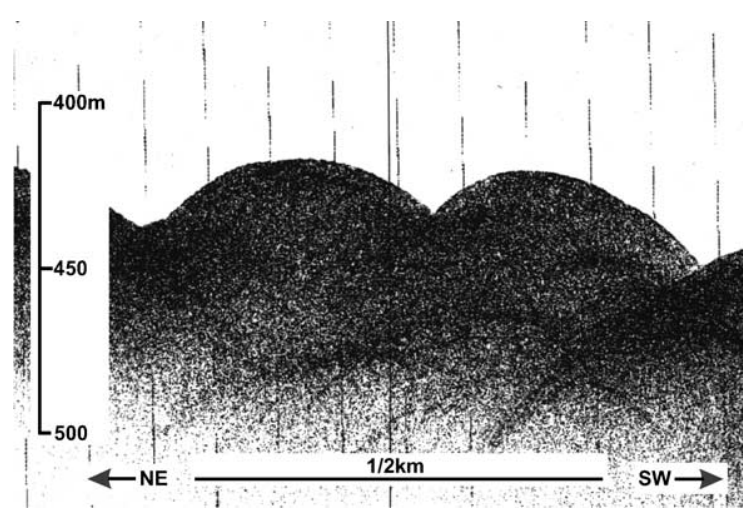

Fig. 6. Type IIIC seabed $-3.5 \mathrm{kHz}$ record showing regular, overlapping hyperbolae with varying vertex elevations above the seafloor and no subbottom reflectors. Vertical relief between the ridges and the submarine canyons between the ridges is up to $150 \mathrm{~m}$. This acoustic facies is observed along the inner-shelf side of the George V Basin, which appears incised with small gullies and canyons right to the deepest part of the basin. The seabed is likely to be crystalline basement outcrop eroded by numerous small outlet glaciers advancing across the inner shelf. The profile was collected close to the coast near the Mertz Glacier Tongue in $430 \mathrm{~m}$ of water (Fig. 1). 
over this area during the WEGA expedition exhibit highly reflective, parabolic reflectors suggestive of crystalline basement cropping out at the seafloor (Brancolini and Harris 2000). Exposed bedrock along the coast of George V Land and adjacent to the George $\mathrm{V}$ Basin comprise a crystalline basement complex of granite, gneiss and high-grade metamorphic rocks (Domack and Anderson 1983; Domack 1987). As the inner shelf appears to be the least explored by vessels, it is useful to compare this area with other studies in comparable environments on the East Antarctic shelf. On the Mac Robertson Land inner shelf, west of Prydz Bay, Harris and O'Brien (1996) noted high-relief ridges/pinnacles and valleys/ depressions, which are apparently caused by metamorphic basement outcrop. On the inner shelf of Prydz Bay, O'Brien and Leitchenkov (1997) record a similar acoustic facies with steep pinnacles, tens of metres above the seafloor with narrow valleys, corresponding to regions of Precambrian basement outcrop. If the ridges and canyons observed in the Tangaroa profiles were caused by an advancing ice sheet across the innershelf, then it is likely that the high relief morphology is a result of ice-eroded crystalline basement outcrop. This echo type extends from the shallow coast right to the edge of the deepest part of the George V Basin, and makes up some $20 \%$ of the shelf under study.

\subsection{Larger geomorphic feature}

\subsubsection{Ridge or lateral moraine}

A broad ridge was found on the southern margin of the Mertz Bank, due north of the Mertz Glacier Tongue. A $12 \mathrm{kHz}$ echo sounder captured the only image as the Tangaroa traversed the Mertz Bank (Fig. 7). The image shows the ridge with vertical relief of some $50 \mathrm{~m}$ above the surrounding seabed. This ridge corresponds to the large asymmetric ridge in Barnes (1987) and lateral moraine in Domack et al. (1989), and is believed to be related to ice shelf advances onto the shelf, producing linear deposits of glacial moraine rimming the Mertz Bank at approximately $200 \mathrm{~m}$ water depth. ArcGIS was used to project the position of the ridge in Barnes (1987) and lateral

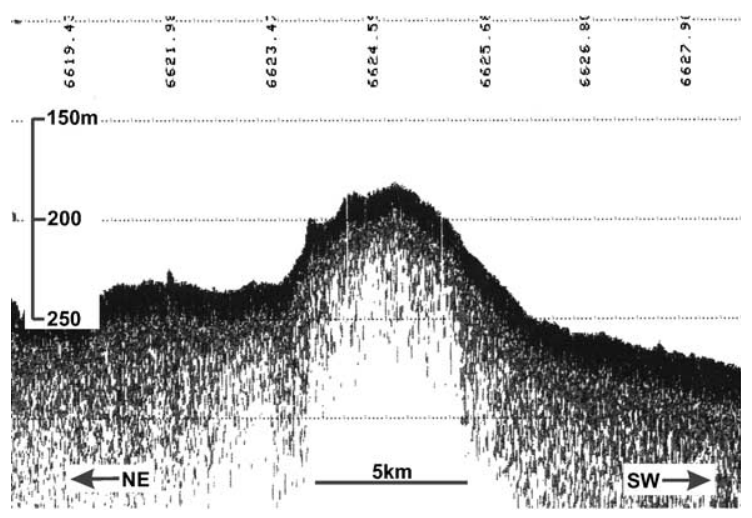

Fig. 7. Ridge or lateral moraine $-12 \mathrm{kHz}$ echo profile of a $50 \mathrm{~m}$ high broad ridge on the southern margin of the Mertz Bank in $230 \mathrm{~m}$ water depth, due north of the Mertz Glacier Tongue. This ridge corresponds to the large asymmetric ridges in Barnes (1987) and lateral moraine in Domack et al. (1989), believed to be related to ice shelf advance onto the shelf during the LGM, producing a linear moraine rimming the southern side of the Mertz Bank at approximately $200 \mathrm{~m}$ water depth (Fig. 1).

moraine in Domack et al. (1989) with the position of the ridge discovered by the WEGA expedition to create a narrow polygon confidently representing the ridge on the southern rim of the Mertz Bank (Fig. 2). The available data and previously published reports do not allow the western limit of the ridge to be plotted with confidence; therefore, the ridge terminates at approximately longitude $145.3^{\circ}$ West. The area occupied by this moraine ridge is less than $1 \%$ of the shelf under study.

\section{Direction of glacial flow}

When the megaflutes or ridge and swale features on the Type IIB seabed are traversed at different directions by the Tangaroa, the returns show systematic differences in appearance. Near the Mertz Glacier, east-southeast oriented profiles show clearly defined ridges (Fig. 8a). The same elongate ridges, when seen from a northeast oriented profile, show broader ridges with gentler slopes and side echoes (Fig. 8b). The differences in appearance result from the northeast profile (Fig. 8b) imaging oblique sections of the same ridges. An important distinction is that when an 

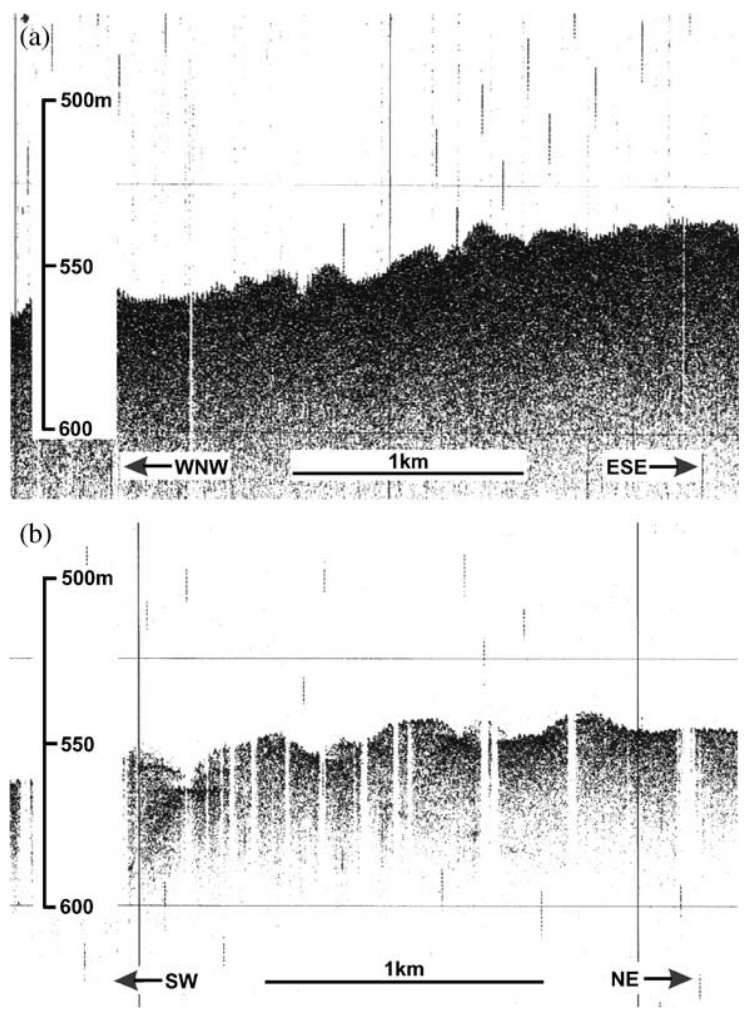

Fig. 8. (a) A $3.5 \mathrm{kHz}$ profile of a Type IIB seabed with megaflutes oriented at between $50^{\circ}$ and $8^{\circ}$ to the east-southeast profile, in a position close to the Mertz Glacier Tongue. Subglacial moulding of the seabed probably forms megaflute ridges as the Mertz Glacier advanced along the floor of the George V Basin. (b) A $3.5 \mathrm{kHz}$ record of a Type IIB seabed for a northeast-oriented profile showing megaflutes in the same location as the profile in Fig. 8a. Ridges are now more elongated than those in Fig. 8a with side echoes, indicating that megaflutes are oriented between north and northwest in this location.

ice-keel turbate Type IA-2 seabed is traversed at different directions and profiles are compared, there is not the difference in appearance as found over megaflutes on a Type IIB seabed, confirming the more random scouring of the seafloor, as expected by grounded bergs.

When the orientation of the megaflutes is investigated across the study area, it is found that near the Mertz Glacier Tongue, ridges are oriented between a north to northwest direction. In the center of the George V Basin, megaflutes are oriented in a more westerly direction, and north of the Mertz Drift in the vicinity of the sill, megaflutes are oriented in a northwest to north direction. The megaflutes average approximately $280 \mathrm{~m}$ apart close to the Mertz Glacier and are slightly wider apart (average of $470 \mathrm{~m}$ ) near the sill closer to the shelf break. Thus, there appears to be a general broadening of megaflutes away from the glacial source.

An interpretation of the megaflutes is that they represent subglacial moulding of the seafloor during ice advance over older compacted seafloor. Thus, ice from an expanded Mertz Glacier initially advanced in a north to northwest direction, obviously following the George V Basin, then veered towards the sill separating the basin from the continental slope (Fig. 2). These findings are in agreement with earlier results of Domack et al. (1989) who showed that the fluted seabed reflects ice-flow direction, and the ridge or lateral moraine around the southern edge of the Mertz Bank records the limit of the expanded glacial margin during the LGM.

\section{Discussion}

Based on the results presented above, the shelf can be divided into four acoustic facies: Type IA-2 (ice-keel turbate); Type IB (SMO drift, drape and fill deposits); Type IIB (smooth diamicton and megaflutes); and Type IIIC (high relief ridges and canyons). The glacial and oceanographic processes that have created these complex bedforms are best explained chronologically from the LGM to the present open marine phase, and shown diagrammatically in Fig. 9.

\subsection{Last Glacial Maximum}

The observation of lateral moraines (Barnes, 1987), and overcompacted sediments at the shelf break (Domack, 1982), indicates that the Mertz Glacier Tongue expanded across the George V Basin during the LGM and previous glaciations (Fig. 9a). However, dates for constraining the LGM in this area have been problematic (Domack et al., 1991). Recently obtained radiocarbon dates of glacial diamicton from the George V Basin puts 

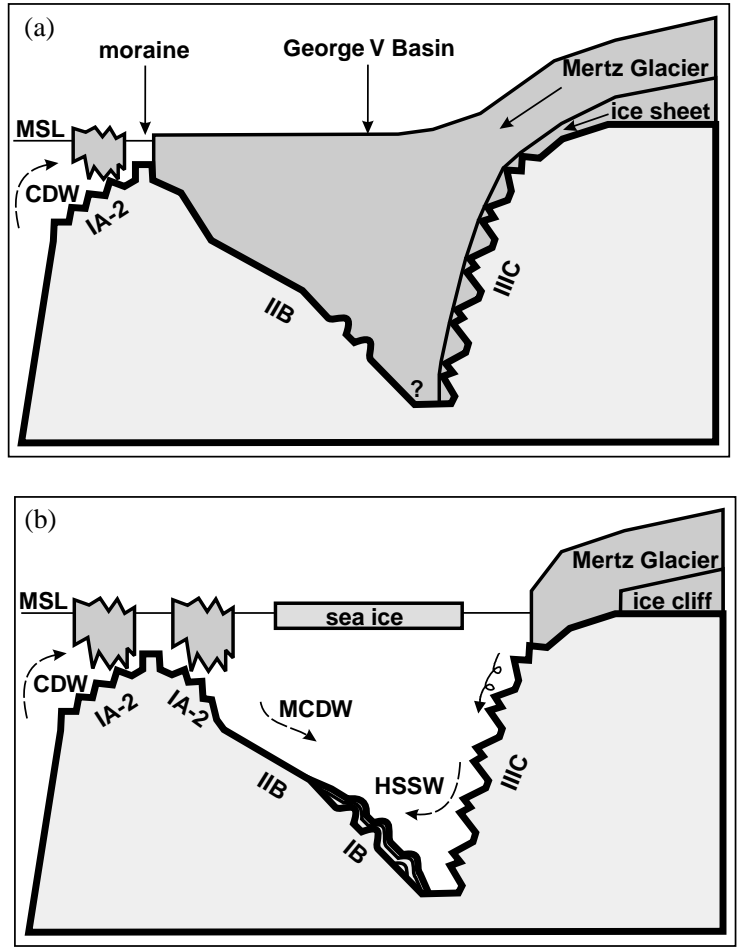

Fig. 9. Diagrams summarizing the processes that have created the acoustic facies of the George V Land shelf. (a) Glacial advance of an expanded Mertz Glacier along the axis of the George V Basin during the LGM and previous glaciations resulted in a Type IIB seabed of smooth diamicton and subglacially formed megaflutes. A lateral moraine in depths of approximately $200 \mathrm{~m}$ along the southern side of the Mertz Bank records the northern limit of the expanded glacier. The effect of impinging CDW over the shelf is limited to the seaward margin of the lateral moraine. Type IA-2 seabed, from ice-keel turbation by grounded bergs, is also limited to the outer-shelf. The advance of numerous outlet glaciers along the ice sheet margin during the LGM and other glaciations eroded crystalline basement outcrop resulting in Type IIIC ridges and canyons. $\mathrm{MSL}=$ mean sea level. (b) At the end of the LGM and after approximately $12 \mathrm{kyr} \mathrm{BP}$, the retreat of the Mertz Glacier Tongue opened the continental shelf to further iceberg gouging of the seabed. Open marine conditions during the Holocene increased biogenic sedimentation within the basin due to the effect of MCDW winnowing outer-shelf banks of finegrained sediments and transporting suspended sediment landward. Deep basin currents associated with the sinking, cooling and mixing of MCDW with HSSW resulted in Type IB SMO deposits within the basin. Retreat of the ice sheet margin to form the present ice cliffs along the coast exposed the high relief inner-shelf to the action of currents. The numerous Type IIIC canyons on the steep inner-shelf would provide a conduit for gravity flows slumping to the bottom of the George V Basin. deposition during the LGM between 17 and $30 \mathrm{kyr}$ BP (Harris et al., 2001), and at a time when the eustatic sea level was approximately $125 \mathrm{~m}$ below present (Fleming et al., 1998). The barrier of the relatively shallow Mertz Bank, due north of the glacier outlet, deflected the ice to the northwest (in this study area) along the axis of the basin, before it turned north towards the shelf break (Fig. 2). Diamicton from cores collected in the deep, inner basin are interpreted as being subglacial, deposited under an expanded ice tongue (Domack et al., 1989; Domack et al., 1991), resulting in the Type IIB seabed. Megaflutes observed below $500 \mathrm{~m}$ depth in the George V Basin record the glacial advance in the form of morainal features over the older compacted seafloor.

Having advanced close to the shelf break, the ice tongue left a well-defined lateral moraine or ridge on the inner margin of the Mertz Bank at about $200 \mathrm{~m}$ depth (Barnes, 1987; Domack et al., 1989). If the lateral moraine marks the northern limit of expansion during the LGM, then most iceberg turbation of the seafloor by calving icebergs would have occurred seaward of this ridge on the Mertz Bank. Presently, in addition to the action of calving bergs on the seabed, this area is subject to strong bottom currents by impinging Circumpolar Deep Water (CDW) that sort relict diamicton and redistribute fine-grained sediment (Domack, 1988; Dunbar et al., 1985). If such currents were operating during the period of glacial expansion, then there was a much reduced area of the shelf to act upon, and therefore a limit to the reworking of glacial and glacial-marine sediments.

At the same time as the advance of the Mertz Glacier, the ice sheet margin that comprises the majority of the George V Land coastline is also likely to advance (Fig. 9a). While most of the ice drainage occurs via the Mertz Glacier (Domack and Anderson, 1983), the eroding action of dozens of small outlet glaciers along the coast during the LGM and past glacial advances probably explains the many canyons found along the inner-shelf. The high relief ridges and canyons corresponding to the Type IIIC seabed on the inner-shelf probably represents erosion of crystalline basement outcrop by an expanded ice sheet (Fig. 9a). Sediments on 
the inner-shelf are likely to be comprised mostly of diamicton with gravity flows and debris lobes.

\subsection{Glacial retreat phase}

With the end of the LGM and the subsequent global rise in relative sea level (Fleming et al., 1998), dramatic changes occurred over the shelf (Fig. 9b). The glacial retreat phase is marked by a distinct transition from sub-ice shelf to openmarine conditions, interpreted from cores collected from the Mertz Drift in the west of the George V Basin (Domack et al., 1989; Harris et al., 2001). Biogenic sediments in contact with diamicton in these cores are massively bedded with a large component of ice-rafted debris (IRD), and deposited after $12 \mathrm{kyr}$ BP (Harris et al., 2001). The IRD in this sedimentary facies is believed to be related to the concentration of icebergs by winds at the calving line (Domack and Harris, 1998). Studies on terrestrial data in East Antarctica show that ice retreat from shelf areas was underway by 11-10 kyr BP (Ingólfsson et al., 1998).

With glacial retreat, the George V Basin would have been open to icebergs and sea ice (Fig. 9b). Previous observations of the Mertz Bank seafloor show that iceberg gouging has a significant impact on moving sediment and influencing surficial sedimentary stratigraphy at depths shallower than $500 \mathrm{~m}$ (Barnes, 1987). Barnes and Lien (1988) record ice gouges on the seafloor from iceberg keels as much as $30 \mathrm{~m}$ wide and approximately $1 \mathrm{~m}$ deep. Ice gouges occur on the Mertz Bank top and the slope to water depths of nearly $500 \mathrm{~m}$, resulting in the Type IA-2 seabed. Ice-keel turbation since the LGM has thus obscured any subglacial features such as megaflutes shallower than $500 \mathrm{~m}$ water depth.

\subsection{Open marine phase}

The open-marine conditions that mark the Holocene have affected an increase in biogenic sedimentation of SMO in the George V Basin (Domack, 1988). Domack and Anderson (1983) attributed the increased winnowing of sediments by CDW on the outer-shelf for the increasing proportion of SMO within the basin. Once on the shelf, modified Circumpolar Deep Water (MCDW) cools, sinks and flows landwards, carrying suspended fine-grained sediment (Dunbar et al., 1985). Within the basin, MCDW mixes with High-Salinity Shelf Water (HSSW) produced through brine rejection from the formation of sea ice, and flows out of the trough across the sill as Antarctic Bottom Water (Rintoul, 1998; Bindoff et al., 2000). Below a depth of $500 \mathrm{~m}$ on the shelf, where the tilling action by icebergs is reduced and settling velocities are favourable, SMO begins to drape the smooth Type IIB seabed and subglacially formed megaflutes. Below $750-850 \mathrm{~m}$ water depth, SMO has accumulated and formed the Mertz Drift, which displays a mounded architecture indicative of a 'confined drift' as defined by Faugéres et al. (1999). This is particularly evident in the southwest of the Mertz Drift, which appears linked to current-controlled depositional processes associated with the production of HSSW (Harris and Beaman, 2003). The extensive northeast part of the Mertz Drift displays a drape-and-fill architecture that thins towards the shelf break, and appears to confirm that the major sediment source is the broad outer-shelf bank. The present study located three other thick SMO deposits within the deeper eastern basin that also have a drape and fill architecture. The SMO deposits have the effect of locally smoothing the seafloor, and are most obvious in the northeast part of the Mertz Drift, which appears to overlie an area of megaflutes.

Ingólfsson et al. (1998) stated that by $5000 \mathrm{yr}$ BP most Antarctic glaciers had retreated to or behind their present positions. The dozens of small outlet glaciers from the ice sheet margin also would have retreated to form the present ice cliffs along the coast. With mean sea level stabilized and the shallow inner-shelf exposed to the action of currents, the numerous canyons of the Type IIIC seabed would provide a conduit for gravity flows. Siliceous and calcareous sand, gravel and sandy gravelly mud collected close to the George V Land coast during 'Operation Deep Freeze' (Domack, 1988) are likely to be the material that contribute to gravity flows down the steep inner-shelf. The slumping of material down the submarine canyons to the basin floor would have the effect of 
flattening the seabed in the deepest part of the George V Basin, contributing to the smooth Type IIB seabed observed here.

\section{Conclusions}

Based on WEGA expedition echo-sounder data and other cruise reports, a baseline map of the acoustic facies of the George V Land continental shelf have been constructed, utilizing the Damuth (1978, 1980) classification scheme. Four echo character types were observed:

(a) Type IA-2 seabed-an ice-keel turbate on the mid- to outer-shelf where the seabed is less than $500 \mathrm{~m}$ deep.

(b) Type IB seabed-SMO drift, drape and fill deposits within the George V Basin, predominantly below $750 \mathrm{~m}$ depth and overlying a Type IIB seabed.

(c) Type IIB seabed-smooth diamicton and subglacially formed megaflutes within the George V Basin where the seabed is below $500 \mathrm{~m}$ depth.

(d) Type IIIC seabed-high relief ridges and canyons on the inner-shelf, in depths from the coastline to below $1000 \mathrm{~m}$ depth in the George V Basin, comprised mostly of eroded crystalline basement outcrop.

The glacial and oceanographic processes that have created the four distinct acoustic facies are explained chronologically from the LGM to glacial retreat phase and then to the present open marine phase:

(1) Last Glacial Maximum. Glacial advance of an expanded Mertz Glacier along the axis of the George V Basin during the LGM and previous glaciations resulted in a Type IIB seabed of smooth diamicton and subglacially formed megaflutes. A lateral moraine in depths of approximately $200 \mathrm{~m}$ along the southern side of the Mertz Bank records the northern limit of the expanded glacier. A Type IA-2 seabed, caused by ice-keel turbation from grounded bergs, is limited to the outershelf. The advance of numerous outlet glaciers along the ice sheet margin during the LGM and other glaciations eroded crystalline basement outcrop, resulting in a Type IIIC seabed of ridges and canyons.

(2) Glacial retreat phase. At the end of the LGM and after approximately $12 \mathrm{kyr} \mathrm{BP}$, the retreat of the Mertz Glacier Tongue resulted in a distinct transition from sub-ice shelf to open marine conditions. The continental shelf became exposed to further iceberg gouging of the seafloor, increasing the shelf area covered by Type IA-2 seabed.

(3) Open marine phase. Open marine conditions during the Holocene increased biogenic sedimentation within the basin due to the effect of modified Circumpolar Deep Water (MCDW) winnowing outer-shelf banks of fine-grained sediments and transporting suspended sediment landward. Deep basin currents associated with the sinking, cooling and mixing of MCDW with high salinity Shelf Water (HSSW) resulted in Type IB siliceous mud and diatom ooze (SMO) deposits within the basin. Retreat of the ice sheet margin to form the present ice cliffs along the coast exposed the high relief inner-shelf to the action of currents. The numerous Type IIIC canyons on the steep inner-shelf could provide a conduit for gravity flows slumping to the bottom of the George V Basin.

Our acoustic facies map confirms previous work in the area and increases the detail of boundaries between the various seafloor morphologies across the shelf. An understanding of the long-term processes on a geological scale that have controlled the form of the seabed, as well as the modern contemporary processes which influence the seabed and its biota, will be useful for future studies on marine habitats on the East Antarctic shelf.

The interpretation of WEGA echo-sounder data to produce seafloor morphology and acoustic facies maps provides the primary data set on which to base the mapping of marine benthic habitats on the George V Land shelf. The mapping of marine habitats requires a knowledge and understanding of the long-term processes on a 
geological scale that have controlled the form of the seabed as well as the modern contemporary processes that influence the seabed and its biota.

\section{Acknowledgements}

We are grateful to the captain and crew of the R.V. Tangaroa and the rest of the WEGA expedition team for collecting this high-quality data. We would also like to thank Dr Richard Coleman and Dr Eleanor Bruce from University of Tasmania for their support and assistance with the GIS, and Mr Rick Smith from Geoscience Australia for assisting with the data sets.

\section{References}

Barnes, P.W., 1987. Morphological studies of the Wilkes Land continental shelf, Antarctica - glacial and iceberg effects. In: Eittreim, S.L., Hampton, M.A. (Eds.), The Antarctic Continental Margin: Geology and Geophysics of Offshore Wilkes Land, CPCEMR Earth Science Series. CircumPacific Council for Energy and Mineral Resources, Houston, TX, pp. 175-194.

Barnes, P.W., Lien, R., 1988. Icebergs rework shelf sediments to $500 \mathrm{~m}$ off Antarctica. Geology 16, 1130-1133.

Bindoff, N.L., Rintoul, S.R., Massom, R.A., 2000. Bottom Water formation and polynyas in Adélie Land, Antarctica. Papers and Proceedings of the Royal Society of Tasmania 133 (3), 51-56.

Brancolini, G., Harris, P.T., 2000. Post Cruise Report AGSO Survey 217: Joint Italian/Australian Marine Geoscience Expedition Aboard the R.V. Tangaroa to the George Vth Land Region of East Antarctica during February-March, 2000. AGSO Record No. 2000/38, Australian Geological Survey Organisation, Canberra.

Chapman, F., 1922. Sea-floor deposits from soundings, Vol. II. Oceanography, Part I. Australasian Antarctic Expedition 1911-14, Sydney.

Damuth, J.E., 1978. Echo character of the Norwegian-Greenland Sea: relationship to Quaternary sedimentation. Marine Geology 28, 1-36.

Damuth, J.E., 1980. Use of high-frequency $(3.5-12 \mathrm{kHz})$ echograms in the study of near-bottom sedimentation processes in the deep sea: a review. Marine Geology 38, $51-75$.

Domack, E.W., 1982. Sedimentology of glacial and glacial marine deposits on the George V-Adélie continental shelf, East Antarctica. Boreas 11, 79-97.

Domack, E.W., 1987. Preliminary stratigraphy for a portion of the Wilkes Land continental shelf, Antarctica: evidence from till provenance. In: Eittreim, S.L., Hampton, M.A. (Eds.), The Antarctica Continental Margin: Geology and Geophysics of Offshore Wilkes Land, CPCEMR Earth Science Series. Circum-Pacific Council for Energy and Mineral Resources, Houston, Texas, pp. 195-203.

Domack, E.W., 1988. Biogenic facies in the Antarctic glacimarine environment: basis for a polar glacimarine summary. Palaeogeography, Palaeoclimatology, Palaeoecology 63, 357-372.

Domack, E.W., Anderson, J.B., 1983. Marine geology of the George V continental margin: combined results of Deep Freeze 79 and the 1911-14 Australasian Expedition. In: Oliver, R.L., James, P.R., Jago, J.B. (Eds.), Fourth International Symposium on Antarctic Earth Sciences. Antarctic Earth Science. Australian Academy of Science, South Australia, pp. 402-406.

Domack, E.W., Harris, P.T., 1998. A new depositional model for the ice shelves, based upon sediment cores from the Ross Sea and Mac. Robertson shelf, Antarctica. Annals of Glaciology 27, 281-284.

Domack, E.W., Jull, A.J.T., Anderson, J.B., Linick, T.W., Williams, C.R., 1989. Application of tandem accelerator mass-spectrometer dating to Late Pleistocene-Holocene sediments of the East Antarctic continental shelf. Quaternary Research 31, 277-287.

Domack, E.W., Jull, A.J.T., Nakao, S., 1991. Advance of the East Antarctic outlet glaciers during the Hypsithermal: implications for the volume state of the Antarctic ice sheet under global warming. Geology 19, 1059-1062.

Dunbar, R.B., Anderson, J.B., Domack, E.W., 1985. Oceanographic influences on sedimentation along the Antarctic continental shelf. In: Jacobs, S.S. (Ed.), Oceanology of the Antarctic Continental Shelf. Antarctic Research Series, Vol. 43. American Geophysical Union, Washington, DC, pp. 291-312.

Faugères, J.C., Stow, D.A.V., Imbert, P., Vianna, A., 1999. Seismic features diagnostic of contourite drifts. Marine Geology 162, 1-38.

Fleming, K., Johnston, P., Zwartz, D., Yokoyama, Y., Lambeck, K., Chappell, J., 1998. Refining the eustatic sealevel curve since the Last Glacial Maximum using far- and intermediate-field sites. Earth and Planetary Science Letters 163, 327-342.

Harris, P.T., Beaman, R.J. 2003. Processes controlling the formation of the Mertz Drift, George Vth continental shelf, East Antarctica: evidence from $3.5 \mathrm{~Hz}$ sub-bottom profiling and sediment cores. Deep Sea Research II, this issue (doi: 10.1016/S0967-0645(03)00070-5)

Harris, P.T., O’Brien, P.E., 1996. Geomorphology and sedimentology of the continental shelf adjacent to Mac. Robertson Land, East Antarctica: a scalped shelf. GeoMarine Letters 16, 287-296.

Harris, P.T., Domack, E.W., Manley, P.L., Gilbert, R., Leventer, A., 1999. Andvord drift: a new type of inner shelf, glacial marine deposystem from the Antarctic Peninsula. Geology 27 (8), 683-686. 
Harris, P.T., Brancolini, G., Armand, L., Brusetti, M., Beaman, R.J., Giorgetti, G., Presti, M., Trincardi, F., 2001. Continental shelf drift deposit indicates non-steady state Antarctic bottom water production in the Holocene. Marine Geology 179 (1-2), 1-8.

Ingólfsson, Ó., Hjort, C., Berkman, P.A., Björck, S., Colhoun, E., Goodwin, I.D., Hall, B., Hirakawa, K., Melles, M., Möller, P., Prentice, M.L., 1998. Antarctic glacial history since the Last Glacial Maximum: an overview of the record on land. Antarctic Science 10 (3), 326-344.

IOC, 1997. GEBCO-97: the 1997 edition of the General Bathymetric Chart of the Oceans (GEBCO) Digital Atlas. British Oceanographic Data Centre, on behalf of the Intergovernmental Oceanographic Commission (IOC) and the International Hydrographic Organisation (IHO), Birkenhead, UK.

Karl, H.A., 1989. High-resolution seismic-reflection interpretations of some sediment deposits, Antarctic continental margin: focus on the western Ross Sea. Marine Geology 85, 205-223.

Leventer, A., 1992. Modern distribution of diatoms in sediments from the George V Coast, Antarctica. Marine Micropaleontology 19, 315-332.

Leventer, A., Brachfield, S., Domack, E.W., Dunbar, R., Manley, P., McClennen, C., 2001. Coring Holocene Antarctic Ocean Sediments-NBP0101 Cruise Report.
Massom, R.A., Hill, K.L., Worby, A.P., Paget, M., Allison, I., 2001. Effects of regional fast-ice and iceberg distributions on the behaviour of the Mertz Glacier polynya, East Antarctica. Annals of Glaciology 33, 391-398.

O'Brien, P.E., Leitchenkov, G., 1997. Deglaciation of Prydz Bay, East Antarctica, based on echo sounder and topographic features. In: Barker, P.F., Cooper, A.K. (Eds.), Geology and Seismic Stratigraphy of the Antarctic Margin. Antarctic Research Series, Vol. 71. American Geophysical Union, Washington, DC, pp. 109-125.

Rintoul, S.R., 1998. On the origin and influence of Adélie Land Bottom Water. In: Jacobs, S.S., Weiss, R.F. (Eds.), Ocean, Ice and Atmosphere: Interactions at the Antarctic Continental Margin. Antarctic Research Series, Vol. 75. American Geophysical Union, Washington, DC, pp. $151-171$.

Vanney, J.-R., Johnson, G.L., 1979. The sea floor morphology seaward of Terre Adélie (Antarctica). Deutsche Hydrographsiche Zeitschrift 32 (H2), 77-87.

Von der Borch, C.C., Oliver, R.L., 1968. Comparison of heavy minerals in marine sediments with mainland rock outcrops along the coast of Antarctica between longitudes $40^{\circ} \mathrm{E}$ and $150^{\circ} \mathrm{E}$. Sedimentary Geology 2, 77-80. 